\title{
FAKTOR YANG BERHUBUNGAN DENGAN KEJADIAN STUNTING PADA BALITA
}

\author{
${ }^{1)^{*}}$ Zurhayati, ${ }^{2)}$ Nurul Hidayah \\ D III Kebidanan, Akademi Kebidanan Sempena Negeri Pekanbaru \\ Jl. Soekarno Hatta, Gang Handayani I No I Arengka Pekanbaru-Riau-Indonesai \\ Email : ${ }^{1)^{*}}$ zurhayati2112@gmail.com, ${ }^{2}$ batrisya.assyifa@gmail.com
}

Kata Kunci:

Stunting, Pendidikan, Pendapatan, kunjungan ANC

Keywords:

Stunting, Education,

Income, ANC visits

\section{Info Artikel}

Tanggal dikirim: 15-3-2021

Tanggal direvisi: 06-8-2021

Tanggal diterima: 23-1-2022 DOI Artikel:

10.36341/jomis.v6i1.1730 Creative Commons AttributionNonCommercial-ShareAlike 4.0 International License.

\begin{abstract}
ABSTRAK
Stunting merupakan masalah gizi yang mengacu pada kualitas kehidupan anak, dilihat dari tumbuh kembangnya yang tidak sesuai dengan kemampuan genetiknya. Terhambatnya pertumbuhan dan perkembangan balita di sebabkan stunting. Chilhood stunting atau disebut dengan tubuh pendek pada anak adalah kurangnya gizi atau gagalnya tumbuh di masa lampau, digunakan untuk penilaian jangka panjang gizi kurang pada anak. Kasus yang banyak di temukan di Negara berkembang adalah stunting, termasuk Indonesia. Tujuan penelitian untuk mengetahui faktor yang berhubungan dengan kejadian stunting pada balita di wilayah Kerja UPT Puskesmas Tanjung Batu Kepri. Penelitian dengan jenis kuantitatif menggunakan desain penelitian analisis korelasi dengan pendekatan cross-sectional. Populasi penelitian merupakan keseluruhan balita di wilayah kerja UPT Puskesmas Tanjung Batu Kepri sampel yang diambil sebanyak 97 balita dengan menggunakan teknik consecutive sampling. Pengumpulan data menggunakan data primer dengan menggunakan kuesioner dan pemeriksaan. Analisa data menggunakan univariat dan bivariat dengan uji chi-square. Hasil dari penelitian ini ada hubungan pendidikan dengan kejadian stunting yang mana nilai $P$-value adalah $0,15<0,1$. Ada hubungan pendapatan dengan kejadian stunting yang mana nilai $P$-value adalah $0,000<0,1$. Ada hubungan kunjungan ANC dengan kejadian stunting dengan nilai $P$-value adalah $0,004<0,1$. Perlu ditingkatkan pemberian informasi khususnya pada ibu-ibu mengenai pencegahan terjadinya stunting.
\end{abstract}

\begin{abstract}
Stunting is a nutritional problem that refers to the quality of life of children, seen from their growth and development that is not in accordance with their genetic abilities. Delayed growth and development of toddlers is caused by stunting. Childhood stunting or short stature in children is a lack of nutrition or failure to thrive in the past, which is used for long-term assessment of malnutrition in children. Cases that are often found in developing countries are stunting, including Indonesia. The purpose of the study was to determine the factors associated with the incidence of stunting in children under five in the working area of the Tanjung Batu Kepri Health Center UPT. This type of quantitative research uses a correlation analysis research design with a crosssectional approach. The study population was all children under five in the working area of the Tanjung Batu Kepri Health Center UPT sample taken as many as 97 toddlers using a consecutive sampling technique. Collecting data using primary data by using questionnaires and examinations. Data analysis used univariate and bivariate with chi-square test. The results of this study have a relationship between education and the incidence of stunting where the P-value is $0.15<0.1$. There is a relationship between income and stunting where the $P$-value is $0.000<0.1$. There is a relationship between ANC visits and the incidence of stunting with a P-value of $0.004<0.1$. It is necessary to improve the provision of information, especially to mothers regarding the prevention of stunting.
\end{abstract}




\section{PENDAHULUAN}

Stunting termasuk gangguan pertumbuhan pada anak usia dua tahun kebawah. terjadi pada periode seribu hari pertama dari dalam kandungan yang akan berdampak bagi kelangsungan hidup anak [1]. Badan tidak tinggi, beresiko memiliki berat badan lebih dan berkurangnya kesehatan reproduksi serta menurunnya kemampuan produktif suatu bangsa adalah dampak dari stunting [2].

Gizi buruk berpengaruh pada kualitas kehidupan anak sebagai pencapain pertumbuhan dan perkembangan anak yang optimal adalah dampak dari stunting. Oleh karenanya stunting dapat menjadi penghambat proses pertumbuhan perkembangan pada anak. Chilhood stunting atau tubuh tidak tinggi merupakan faktor dari kekurangan gizi kronis dapat di artikan dengan kegagalan pertumbuhan di masa lalu dan digunakan sebagai penilaian jangka panjang untuk gizi kurang pada anak [3].

Balita dengan stunting seharusnya mendaptkan perhatian khusus karena stunting tersebut menjadi penyebab hambatan pertumbuhan balita, mental, dan kesehatan anak. Pembahasan yang banyak di bincangkan saat ini anak dengan stunting mengalami penurunan prestasi belajar, sehingga berdampak pada pendapatan yang rendah pada masa dewasa. Tumbuh menjasi individu yang tidak sehat dan miskin saat dewasa sering di alami oleh anak dengan stunting. Kerentanan pada penyakit juga di timbulkan dari faktor stunting, baik itu penyakit yang menular ataupun Penyakit Tidak Menular (PTM), selain itu kenaikan berat badan yang berlebih juga di karenakan dari faktor stunting yang menyebabkan terjadinya resiko penyakit degeneratif. Oleh karena itu, stunting menjadi predictor rendahnya kualitas sumber daya manusia suatu Negara [4].

Buruknya kemampuan kognitif, menurunnya produktivitas, meningkatnya penyakit yang merugikan dalam jangka panjang bagi ekonomi Indonesia adalah faktor dari stunting [4]. Gizi rendah, morbiditas, infeksi berulang, dan faktor lingkungan merupakan manifestasi jangka panjang dari stunting pada anak. Ibrahim dan kawan-kawan meneliti menunjukkan ada hubungan asupan energi dan protein yang kurang dengan kejadian stunting pada anak usia 24-59 bulan [5].

Penelitian Anisa dengan judul Faktor Kejadian Stunting pada Balita Usia 25-60 Bulan menunjukkan bahwa ada hubungan Berat Badan Lahir (BBL) anak dengan Stunting dan ada hubungan pendapatan per kapita dengan stunting [6]. Penyebab stunting dapat terjadi karena gizi buruk pada balita menyebakan penghambatan perkembangan anak, berdampak negatif berlangsung pada kehidupan selanjutnya menyebabkan penurunan intelektual, beresiko pada penyakit tidak menular, rendahnya produktivitas yang menyebabkan kemiskinan serta risiko terjadinya kelahiran bayi dengan berat badan lahir rendah[7].

Beberpa penyebab yang menyebabkan kejadian stuting yaitu ekonomi berkaitan dengan pendapatan, pendidikan, pengetahuan ibu, banyaknya anggota keluarga. Gizi keluarga dan pendidikan keluarga di pengaruhi oleh pendapatan keluarga [8]. Stunting, gizi kurang merupakan masalah yang belum dapat terselesaikan. Pemerintah membuat kebijakan untuk permasalahan gizi dan stunting. Tahun 2013 dari 32,9 \% menurun menjadi 28, $0 \%$ angka stunting pada anak dibawah dua tahun, Tahun 2019 mengutamakan pembangunan nasional seperti halnya yang tercantum pada (RPJMN) tahun 2015-2019.

Stunting pada balita dipengaruhi oleh tingkat pendapatan dan tingkat pendidikan orang tua yang rendah [9]. Status gizi anak akan lebih baik apabila pendapatan dan pendidikan orang tua baik sehingga dapat memperoleh akses pendidikan dan kesehatan yang baik pula sehingga status gizi anak dapat menjadi baik pula [10]. 
Perbaikan gizi yang dilakukan oleh pemerintah lebih di utamakan pada anak balita, karena pada masa balitalah masa yang memerlukan zat gizi guna untuk pertumbuhan dan perkembangannya. pada masa balita juga memerlukan berbagai ragam macam makanan yang baik, baik itu dari kualitasnya maupun kuantitasnya [11].

Kesehatan serta perkembangan janin sangat di pengaruhi oleh gizi ketika hamil. Tidak optimalnya pertumbuhan selama di kandungan menyebabkan berat badan lahir rendah [12]. Penelitian di Nepal menunjukkan Resiko yang tinggi pada kejadian stunting adalah bayi dengan berat lahir rendah [13]. Selain berat badan lahir rendah Panjang lahir bayi juga ada hubungannya dengan stunting. Sesuai Penelitian di Kendal bayi lahir dengan tinggi badan yang kurang berisiko terhadap stunting pada balita [14].

Stunting yang terjadi di Indonesia pada tahun 2013 mencapai 37,2 persen. Tingkat kejadian stunting di Provinsi Riau pada tahun 2016 mencapai 29,7 persen. Balita stunting (pendek) dan severely stunting (sangat pendek) masih ditemukan di Pekanbaru dengan angka kejadian yaitu balita stunting 6,97 persen dan balita severely stunting 1,69 persen [9].

Dari uraian di atas, pendidikan, Pendapatan serta Kunjungan ANC dapat mempengaruhi terjadinya stunting. Maka peneneliti berminat untuk melakukan penelitian dengan judul "Faktor Yang Berhubungan Dengan Kejadian Stunting Pada Balita". Bertujuan mengetahui faktor yang berhubungan dengan kejadian stunting pada balita.

\section{TINJAUAN PUSTAKA}

Hasil penelitian dengan judul Socioeconomic Factors Associated with Underweight and Stunting yang dilakukan oleh Assefa dkk, menunjukkan Status ekonomi, usia, jenis kelamin, pendidikan adalah faktor dari status gizi remaja berat badan rendah dan stunting [16]. Hal ini sejalan dengan hasil penelitian ini yang mana faktor pendidikan berhubungan dengan kejadian stunting.

Penelitian oleh Mustamin Di Provinsi Sulawesi Selatan menunjukkan bahwa Ibu yang mempunyai pendidikan kurang $27,7 \%$ mempunyai balita yang stunting, sedangkan $27,3 \%$ ibu yang mempunyai pendidikan baik mempunyai balita yang normal kesimpulan dari penelitiannya ada hubungan yang antara tingkat pendidikan ibu dengan kejadian stunting pada balita [17].

Penelitian di Nusa Tenggara Timur oleh Picauly berjudul Analisis determinan prestasi belajar anak sekolah, menunjukkan peran ibu dalam menjaga konsumsi dan status gizi rumah tangga terlihat sangat menonjol. Peran ibu terlihat dari tingkat pengetahuan ibu, informasi, kesehatan, gizi, pengeluaran pangan dan non pangan atau pendapatan [18].

Berdasarkan penelitian yang dilakukan oleh Khoirun Ni'mah kawankawan menunjukan Pendapatan rendah dengan nilai $(\mathrm{OR}=3,250 ; \quad \mathrm{CI}=1,150$ 9,187), Pendidikan rendah dengan nilai $(\mathrm{OR}=3,378 ; \quad \mathrm{CI}=1,246-9,157), \quad$ adalah penyebab terjadinya stunting pada balita [19].

Lutfiana dengan judul penelitiannya Faktor Yang Berhubungan Dengan Kejadian Stunting mendapatkan hasil bahwasannya pekerjaan, pendapatan, dengan riwayat ASI ekslusif dan dengan riwayat BBLR terbukti mempunyai hubungan dengan stunting. dengan nilai pekerjaan $(\mathrm{p}=0,001$ dan $\mathrm{aPOR}=2,89)$, pendapatan keluarga $(\mathrm{p}=0,000$ dan aPOR $=6,26$ ), riwayat ASI eksklusif $(\mathrm{p}=0,000$ dan $\mathrm{aPOR}=3,36)$, riwayat $\mathrm{BBLR}$ ( $\mathrm{p}=0,002$ dan $\mathrm{aPOR}=2,62)$ [20].

Selanjutnya, berdasarkan penelitian yang dilakukan Roudhotun Nasikhah, pendapatan perkapita merupakan faktor terjadinya stunting. Karena kemiskinan dalam waktu yang cukup lama menjadikan keluarga tidak mampu memenuhi kebutuhan pangan yang baik 
[21]. Hal ini sejalan dengan hasil penelitian ini yang mana faktor pendapatan berhubungan dengan kejadian stunting.

Penelitian yang di lakukan oleh Meilyasari menunjukkan panjang badan lahir rendah, prematuritas, usia makan pertama berpengaruh terhadap kejadian stunting pada balita usia 12 bulan [14]

Penelitian yang di lakukan oleh Ningsih saputri, dengan menggunakan uji statistic chi square menunjukkan ada hubungan konsumsi tablet FE, IMD (Inisiasi Menyusui Dini), ASI Eksklusif dengan resiko stunting [22].

\section{METODE}

Penelitian menggunkan jenis penelitian kuantitatif menggunakan pendekatan observasional dan desain penelitian cross sectional bertujuan mencari tahu faktor yang menjadi hubungan dengan kejadian sunting pada balita Di Wilayah Kerja Puskesmas Tanjung Batu Kepri Tahun 2020.

Populasi pada penelitian ini keseluruhan balita di Wilayah Kerja
UPT Puskesmas Tanjung Batu Kepri Tahun 2020, yaitu sebanyak 2935 balita. Sampel dalam penelitian ini menggunakan metode Consecutive Sampling yaitu seluruh objek yang ada yang berurutan kemudian memenuhi kriteria akan di pilih sebagai subjek penelitian sampai subjek yang terpenuhi. dalam penelitian ini di dapatkan subjek penelitian sebanyak 97 balita di wilayah kerja UPT Puskesmas Tanjung Batu Kepri Tahun 2020.

Untuk mendapatkan data variabel independent (Pendapatan, Pendidikan orang tua, Kunjungan Antenatal Care) menggunakan kuesioner. Sedangkan variable dependent (Stunting) menggunakan pengukur tinggi badan dan pita $\mathrm{cm}$. Analisa data dengan Univariat dan dengan Bivariat menggunakan uji chi square.

\section{HASIL DAN PEMBAHASAN}

1) Analisa Univariat

Tabel 1

Distribusi Frekuensi Responden Berdasarkan Pendidikan, Pendapatan, Kunjungan ANC dan Stunting di Wilayah Kerja UPT Puskesmas Tanjung Batu Kepri Tahun 2020

\begin{tabular}{clcc}
\hline No & Variabel & Jumlah & Persentase (\%) \\
\hline & Pendidikan & & \\
1 & Rendah & 52 & 53.6 \\
2 & Sedang & 15 & 15.5 \\
3 & Tinggi & 30 & 30.9 \\
& Jumlah & 97 & 100.0 \\
\hline & Pendapatan & & \\
1 & Tinggi & 21 & 21,6 \\
2 & Sedang & 30 & 30,9 \\
3 & Rendah & 46 & 47,4 \\
& Jumlah & 97 & 100,0 \\
\hline
\end{tabular}




\begin{tabular}{clcc}
\hline & Kunjungan ANC & & \\
1 & Standart & 28 & 28,9 \\
2 & Tidak Standart & 69 & 71,1 \\
& Jumlah & 97 & 100,0 \\
& & & 15,5 \\
\hline & Stunting & & 84,5 \\
1 & Stunting & 15 & 100,0 \\
\hline
\end{tabular}

Tabel 1 di atas yakni 97 responden, terdapat mayoritas responden berpendidikan rendah sebanyak 52 orang $(53,6 \%)$ dan minoritas berpendidikan rendah sebanyak 15 orang $(15,5 \%)$. Dari 97 responden, mayoritas responden berpendapatan rendah sebanyak 45 orang $(47,4 \%)$ dan minoritas berpendapatan tinggi sebanyak $21(21,6 \%)$.
Dari 97 responden, terdapat mayoritas responden dengan Kunjungan ANC tidak terstandart sebanyak 69 orang $(71,1 \%)$ dan minoritas responden dengan Kunjungan ANC Standart sebanyak 28 orang $(28,9 \%)$. Dari 97 responden, mayoritas responden Tidak Stunting sebanyak 82 orang $(84,5 \%)$ dan minoritas Stunting sebanyak 15 orang $(15,5 \%)$.

2) Analisa Bivariat

Tabel 2

Hubungan Pendidikan dengan Kejadian Stunting di Wilayah Kerja UPT Pusekesmas Tanjung Batu Kepri Tahun 2020

\begin{tabular}{|c|c|c|c|c|c|c|c|c|}
\hline \multirow{3}{*}{ Pendidikan } & \multicolumn{4}{|c|}{ Stunting } & \multirow{2}{*}{\multicolumn{2}{|c|}{ Total }} & \multirow{3}{*}{$\boldsymbol{P}$} & \multirow{3}{*}{$\grave{\alpha}$} \\
\hline & \multicolumn{2}{|c|}{ Stunting } & \multicolumn{2}{|c|}{ Tidak Stunting } & & & & \\
\hline & $\mathrm{N}$ & $\%$ & $\mathrm{~N}$ & $\%$ & $\mathrm{~N}$ & $\%$ & & \\
\hline Tinggi & 0 & 0,0 & 20 & 100,0 & 20 & 100,0 & \multirow{4}{*}{0,15} & \multirow{4}{*}{0,1} \\
\hline Sedang & 2 & 8.9 & 23 & 92,0 & 25 & 100,0 & & \\
\hline Rendah & 13 & 25,0 & 39 & 75,0 & 52 & 100,0 & & \\
\hline Jumlah & 15 & 15,5 & 82 & 84,5 & 97 & 100,0 & & \\
\hline
\end{tabular}

Tabel 2 diatas yakni dari 20 responden dengan pendidikan tinggi seluruhnya tidak stunting yaitu 20 orang, dari 25 responden dengan pendidikan sedang sebanyak 2 orang stunting dan 23 orang tidak stunting, dari 52 responden dengan pendidikan rendah, 13 orang stunting dan 39 orang tidak Stunting.
Hasil dari Uji chi-square menunjukkan nilai $\mathrm{P}$-value $=0,15$ dengan kesalahan 0,1 maka Ho ditolak dan Ha diterima artinya Ada hubungan pendidikan dengan kejadian stunting di Wilayah Kerja UPT Puskesmas Tanjung Batu Kepri 2020. 
Tabel 3

Hubungan Pendapatan dengan kejadian Stunting di Wilayah Kerja UPT Puskesmas Tanjung Batu Kepri Tahun 2020

\begin{tabular}{|c|c|c|c|c|c|c|c|c|}
\hline \multirow{2}{*}{$\begin{array}{c}\text { Pendapatan Orang } \\
\text { Tua }\end{array}$} & \multicolumn{4}{|c|}{ Stunting } & \multirow{2}{*}{\multicolumn{2}{|c|}{ Total }} & \multirow{3}{*}{$P$} & \multirow{3}{*}{$\grave{\alpha}$} \\
\hline & \multicolumn{2}{|c|}{ Stunting } & \multicolumn{2}{|c|}{ Tidak Stunting } & & & & \\
\hline & $\mathrm{N}$ & $\%$ & $\mathrm{~N}$ & $\%$ & $\mathrm{~N}$ & $\%$ & & \\
\hline Tinggi & 2 & 9,5 & 19 & 90,5 & 21 & 100,0 & & \\
\hline Sedang & 13 & 43,3 & 17 & 56,7 & 30 & 100,0 & 0,000 & 0,1 \\
\hline Rendah & 0 & 0,0 & 46 & 100,0 & 46 & 100,0 & & \\
\hline Jumlah & 15 & 15,5 & 82 & 84,5 & 97 & 100,0 & & \\
\hline
\end{tabular}

Tabel 3 diatas yakni dari 21 responden yang memiliki pendapatan tinggi, 2 orang stunting dan 19 orang tidak stunting. dari 30 responden yang dengan pendapatan sedang ada 13 orang stunting, dan 17 orang tidak stunting. dari 46 responden yang memiliki pendapatan rendah 46 orang tidak stunting.
Hasil dari uji chi-square menunjukan nilai $\mathrm{P}$-value $=0,00$ dan dengan kesalahan 0,1 maka Ho ditolak dan Ha diterima artinya ada hubungan pendapatan dengan Kejadian Stunting di wilayah kerja UPT Puskesmas Tanjung Batu Kepri Tahun 2020.

Tabel 4

Hubungan Kunjungan ANC dengan Kejadian Stunting di Wilayah Kerja UPT Puskesmas Tanjung Batu Kepri Tahun 2020

\begin{tabular}{|c|c|c|c|c|c|c|c|c|}
\hline \multirow{3}{*}{$\begin{array}{c}\text { Kunjungan } \\
\text { Antenatal Care }\end{array}$} & \multicolumn{4}{|c|}{ Stunting } & \multirow{2}{*}{\multicolumn{2}{|c|}{ Total }} & \multirow{3}{*}{$P$} & \multirow{3}{*}{$\alpha$} \\
\hline & \multicolumn{2}{|c|}{ Stunting } & \multicolumn{2}{|c|}{ Tidak Stunting } & & & & \\
\hline & $\mathrm{N}$ & $\%$ & $\mathrm{~N}$ & $\%$ & $\mathrm{~N}$ & $\%$ & & \\
\hline Standart & 0 & 00,0 & 28 & 100,0 & 28 & 100,0 & & \\
\hline Tidak Standart & 15 & 21,7 & 54 & 78,3 & 69 & 100,0 & 0,004 & 0,1 \\
\hline Jumlah & 15 & 15,5 & 82 & 84,5 & 97 & 100,0 & & \\
\hline
\end{tabular}

Dari tabel diatas terlihat dari 28 responden melakukan kunjungan ANC terstandart seluruhnya yaitu 28 orang tidak stunting. Sedangkan dari 69 responden dengan kunjungan ANC tidak standart ada 15 orang stunting dan 54 orang tidak stunting. Uji chi-square menunjukan nilai $\mathrm{P}$-value $=$ 0,004 dengan kesalahan 0,1 maka Ho ditolak dan Ha diterima artinya Ada hubungan Kunjungan ANC dengan Kejadian Stunting di wilayah kerja UPT Puskesmas Tanjung Batu Kepri Tahun 2020

\section{Hubungan Pendidikan Terhadap Kejadian Stunting}

Hasil dari Uji chi-square menunjukkan nilai $\mathrm{P}$-value $=0,15$ dengan kesalahan 0,1 maka Ho ditolak dan Ha diterima artinya Ada hubungan pendidikan dengan kejadian stunting di Wilayah Kerja UPT Puskesmas Tanjung Batu Kepri 2020.

Proses perubahan pengetahuan, sikap, serta perilaku orang tua, bermaksud untuk meningkatkan gizi masyarakat adalah pengertian dari pendidikan masyarakat. Pendidikan yang tinggi akan meningkatkan 
pengetahuan yang baik, sikap, perilakupun akan menjadi lebih baik. Pendidikan adalah faktor penentu seseorang memahami pengetahuan gizi. Karena pendidikan mempengaruhi kualitas dan kuantitas pangan pada balita [23].

Penelitian yang dilakukan oleh Devi pramita dan kawan-kawan dengan judul Relationship Between Education Of Toddler Mother And Stunting Events In Posyandu Arumdalu VIII Ngronggah Baru In 2019 menyatakan Ada hubungnan pendidikan ibu balita dengan stunting di Posyandu Arumdalu VIII Ngronggah Baru Tahun 2019 [24].

Menurut asumsi peneliti, peneliti menemukan masyarakat di wilayah kerja Puskesmas Tanjung Batu Kepri masih terdapat ibu berpendidikan rendah, yang mana semakin banyak ibu dengan pendidikan rendah maka semakin tinggi angka stunting, pendidikan ibu yang rendah disebabkan oleh pendapatan keluarga yang rendah, mengakibatkan ibu tidak melanjutkan pendidikannya ke jenjang yang lebih tinggi, pendapatan yang rendah secara berkala mempengaruhi tingkat pendidikan seseorang, tingkat pendidikan seseorang mempengaruhi pengetahuan gizi yang dapat menyebabkan terjadinya stunting.

\section{Hubungan Pendapatan dengan Kejadian Stunting}

Hasil dari uji chi-square menunjukan nilai $\mathrm{P}$-value $=0,00$ dan dengan kesalahan 0,1 maka Ho ditolak dan Ha diterima artinya ada hubungan pendapatan dengan Kejadian Stunting di wilayah kerja UPT Puskesmas Tanjung Batu Kepri Tahun 2020.

Pendapatan mempengaruhi gizi dan pendidikan formal sebuah keluarga. Rendahnya pendidikan diikuti dengan pengetahuan yang rendah dapat menyebabkan kejadian malnutrisi [8]. Berdasarkan penelitian yang dilakukan oleh Nadhiroh dan kawan-kawan, ada hubungan keluarga berpendapatan rendah dengan stunting [19]. Berdasarkan penelitian Roudhotun Nasikhah didapatkan pendapatan rendah secara terus menerus menjadi faktor stunting. Kemiskinan dalam waktu yang lama mengakibatkan ketidak mampuan keluarga dalam pemenuhan pangan yang baik [21].

Pendapatan keluarga mempengaruhi kemampuan beli bahan pngan keluarga jenis bahan pangan yang akan dibeli tentunya sesuai dengan kemampuan keluarga yang disesuaikan dengan pendapatan keluarga [26]. Peningkatan kualitas pangan dipengaruhi oleh pola asuh orang tua, kualitas pangan itu sendiri mempengaruhi status gizi pada balita, yang mana polah asuh ini terdiri dari cara ibu menyediakan makanan, dari menyusun menu, mengelola sampai ke penyajian makanan tersebut [27]. Penyajian makanan dengan gizi yang tidak baik, biasanya dipengaruhi oleh faktor ekonomi, dari segi pendapatan rendah, budaya, dan juga pengetahuan orang tua, yang mana semakin baik pengetaguan orang tua dan penyajian makanan maka akan baik pula gizi pada balita [28].

Ekonomi merupakan investasi untuk menurunkan terjadinya stunting, dengan peningkatan ekonomi maka peningkatan status gizi pun akan terjadi, sehingga dapat mencegah terjadinya stunting [29]. Kegagalan pertumbuhan disebabkan oleh kurangnya gizi. Perempuan dengan keadaan stunting akan menghasilkan keturunan yang stunting pula, terjadinya lingkaran kemiskinan, menurunnya sumber daya manusia yang tidak mudah diputuskan [30].

Asumsi peneliti, status ekonomi yang rendah pada suatu keluarga di wilayah kerja Puskesmas Tanjung Batu Kepri dikarena masyarakat di wilayah tersebut bekerja sebagai nelayan dan rata-rata tidak berpenghasilan tetap yang mana penghasilannya tergantung pada hasil lautnya. Pendidikan ibu yang rendah mempengaruhi keterbatasan ekonomi keluarga, ibu dengan pendidikan yang rendah rata-rata tidak bekerja mereka kebanyakan hanya menjadi ibu rumah tangga, secara langsung perekonomian keluarga tidak terbantu, berkaitan dengan pendapatan keluarga, berkaitan dengan belanja pangan, dan berkaitan dengan status gizi yang baik untuk mencegah terjadinya stunting. 


\section{Hubungan Kunjungan ANC dengan kejadian stunting}

Uji chi-square menunjukan nilai $\mathrm{P}$-value $=0,004$ dengan kesalahan 0,1 maka Ho ditolak dan $\mathrm{Ha}$ diterima artinya Ada hubungan Kunjungan ANC dengan Kejadian Stunting di wilayah kerja UPT Puskesmas Tanjung Batu Kepri Tahun 2020.

Penelitian Aulia Mini, menyatakan ada hubungan kuat antara kunjungan ANC dengan kejadian stunting pada balita usia 1259 dan menyimpulkan bahwa kunjungan ANC tidak sesuai dengan standart mempunyai pengaruh besar terhadap terjadinya stunting [31]. Sejalan dengan penelitian Masta dan kawan-kawan dengan judul hubungan kunjungan ANC dengan stunting menunjukan hasil penelitian ada hubungan antara kunjungan ANC dengan

\section{KESIMPULAN}

Terdapat hubungan pendidikan, pendapatan dan kunjungan ANC dengan Stunting di wilayah kerja UPT Puskesmas Tanjung Batu Kepri Tahun 2020.

\section{DAFTAR PUSTAKA}

[1] K. Ikeda, N., Yuki, I., \& Shibuya, "Determinants of reduced child stunting in Cambodia: Analysis of pooled data from three demographic and health surveys.Bulletin of the World Health Organization," in 91, 2013, pp. 341-349.

[2] Kemenkes RI, "Buku saku pemantauan status gizi. Buku Saku Pemantauan Status Gizi Tahun," 2017, pp. 7-11.

[3] Departemen Kesehatan RI, Buku Kesehatan Ibu dan Anak. Jakarta: Kementrian Kesehatan dan JICA, 2016.

[4] H. H. Kyu, H. S. Shannon, K. Georgiades, and M. H. Boyle, "Association of Urban Slum stunting dengan nilai $\mathrm{p}$ sebesar 0,000 $(\mathrm{p}<0,05)[32]$.

Asumsi peneliti, masih adanya kunjungan pertama bagi ibu hamil pada kehamilan usia lima sampai tujuh bulan, sehingga pelayanan yang didapatkan ibu tidak sesuai dengan standart kunjungan pada masa kehamilan, yang menyebabkan adanya perlakuan yang tertinggal untuk ibu hamil seperti pengukuran tinggi badan dan pengukuran lingkar lengan atas, yang mana dari pengukuran tersebut dapat membantu menilai status gizi pada saat kehamilan, yang nantinya berkaitan dengan gizi bayi yang sedang di kandungnya, yang dapat menyebakan stunting bagi bayi yang akan dilahirkkan.

Residency with Infant Mortality and Child Stunting in Low and Middle Income Countries," Biomed Res. Int., vol. 2013, p. 604974, 2013.

[5] I. A. Ibrahim and R. Faramita, "Hubungan Faktor Sosial Ekonomi Keluarga dengan Kejadian Stunting Anak Usia 24 - 59 Bulan di Wilayah Kerja Puskesmas Barombong Kota Makassar Tahun 2014," Al-Sihah Public Heal. Sci. J., vol. 7, 2014.

[6] P. Anisa, "Faktor-faktor Yang Berhubungan dengan Kejadian Stunting pada Balita Usia 25-60 Bulan di Kelurahan Kalibaru Depok Tahun 2012," 2012.

[7] Unicef, "Improving Child Nutrition The achievable imperative for global progress," 2013.

[8] et al Kuntari,K, "Faktor Risiko Malnutrisi pada Balita," Kesmas Natl. Public Heal. J., vol. 7, no. 12, 2013.

[9] Riskesdas, Badan Penelitian dan Pengembangan Kesehatan Kementrian Kesehatan RI. Jakarta, 2013.

[10] Bishawakarma, "Hubungan Tingkat Pendidikan Ibu, Pendapatan Keluarga, 
Kecukupan Protein dan Zinc dengan Stunting (Pendek) Pada Balita Usia 636 bulan di Kecamatan Tembalang Kota Semarang," urnal Kesehat. Masy., vol. 1, no. 2, pp. 617-626, 2011.

[11] D. Sartika and S. Nurmaliza, "BALITA DI KOTA PEKANBARU TAHUN 2017," JOMIS (Journal Midwifery Sci., vol. 2, no. 2, pp. 5559, 2018.

[12] WHO (Word Health Organization), "World Health Statistics 2014," 2014.

[13] et al Paudel, "Faktor Risiko Stunting Pada Balita (24-59 Bulan) Di Sumatera," J. Gizi dan Pangan, vol. 8, no. 3, pp. 177-180, 2012.

[14] and M. I. F. Meilyasari, "FAKTOR RISIKO KEJADIAN STUNTING PADA BALITA USIA 12 BULAN DI DESA PURWOKERTO KECAMATAN PATEBON, KABUPATEN KENDAL," vol. 3, no. 2, pp. 303-309, 2014.

[15] Kementerian Kesehatan Republik Indonesia, "Buletin Stunting. Kementerian Kesehatan Republik Indonesia," 2018.

[16] N. L. Assefa H, Belachew T, "Socioeconomic Factors Associated with Underweight and Stunting among Adolescents of Jimma Zone, South West Ethiopia: A Cross-Sectional Study," Hindawi Publ. Corp. ISRN Public Heal., 2013.

[17] Mustamin; Ramlan Asbar; Budiawan, "TINGKAT PENDIDIKAN IBU DAN PEMBERIAN ASI EKSKLUSIF DENGAN KEJADIAN STUNTING PADA BALITA DI PROVINSI SULAWESI SELATAN," Media Gizi Pangan, vol. 25, no. 1, pp. 25-32, 2018.

[18] M. S. Picauly I, "Analisis determinan dan pengaruh stunting terhadap prestasi belajar anak sekolah di Kupang dan Sumba Timur, NTT," $J$. Gizi dan Pangan, vol. 8, no. 1, p. 5562, 2013.

[19] S. R. Nadhiroh, "Faktor yang berhubungan dengan kejadian," 2010.

[20] O. N. Lutfiana, "FAKTOR-FAKTOR YANG BERHUBUNGAN DENGAN KEJADIAN STUNTING DI WILAYAH KERJA UPT PUSKESMAS KLECOREJO KABUPATEN MADIUN TAHUN 2018," 2018.

[21] and A. M. R. Nasikhah, "FAKTOR RISIKO KEJADIAN STUNTING PADA BALITA USIA 24 - 36 BULAN DI KECAMATAN SEMARANG TIMUR," J. Nutr. Coll., vol. 1, no. 1, pp. 176-184, 2012.

[22] N. Saputri, "FAKTOR RISIKO STUNTING ANAK USIA 24-59 BULAN DI PUSKESMAS SUNGAI RUMBAI , DHARMASRAYA," $J$. midwifery Sempena Negeri, vol. 1, no. 1, pp. 1-9, 2021.

[23] L. Suryani, "FAKTOR YANG MEMPENGARUHI STATUS GIZI BALITA DI WILAYAH KERJA PUSKESMAS PAYUNG SEKAKI PEKANBARU," vol. 1, no. 2, pp. 4753, 2017.

[24] R. K. Devi Pramita Sari, Nabilatul Fanny, "Relationship Between Education Of Toddler Mother And Stunting Events In Posyandu Arumdalu VIII Ngronggah Baru In 2019," ojs.udb, 2019.

[26] D. R. Cintya, Teori\&Konsep Tumbuh Kembang Bayi, Toodler; Anak dan Usia Remaja. Yogyakarta: Nuha Medika, 2015.

[27] S. H. Nurmaliza, "POLA ASUH DALAM PEMBERIAN MAKANAN TERHADAP STATUS GIZI BALITA DI KOTA PEKANBARU TAHUN 2017," JOMIS (Journal Midwifery Sci., vol. 2, no. 1, pp. 1-7, 2018.

[28] B. Hanim, "FAKTOR YANG MEMENGARUHI STATUS GIZI BALITA PENDAHULUAN Berdasarkan data World Health Organitation ( WHO ) pada tahun 2017 lebih dari setengah kematian balita disebabkan oleh penyakit yang dapat dicegah dan diobati melalui intervensi 
sederhana dan terjangk," JOMIS (Journal Midwifery Sci., vol. 4, no. 1, pp. 15-24, 2020.

[29] S. H. John Hoddinott, Harold Alderman, Jere R. Behrman, Lawrence Haddad, "The economic rationale for investing in stunting reduction," Matern. Child Nutr., vol. 9, no. s2, 2012.

[30] A. J. Prendergast and J. H. Humphrey, "The stunting syndrome in developing countries," Publ. Cover Paediatr. Int. Child Heal., vol. 34, no. 4, pp. 250265, 2014.

[31] A. Amini, "HUBUNGAN KUNJUNGAN ANTENATAL CARE (ANC) DENGAN KEJADIAN STUNTING PADA BALITA USIA 12-59 BULAN DI KABUPATEN LOMBOK UTARA PROVINSI NTB TAHUN 2016," 'Aisyiyah Yogyakarta, 2016.

[32] M. Hutasoit et al., "KUNJUNGAN ANTENATAL CARE BERHUBUNGAN DENGAN KEJADIAN STUNTING," vol. 2, 2018. 